\title{
Infrared Spectra of some Sulphate-Reducing Bacteria
}

\author{
By G. H. BOOTH, J. D. A. MILLER, H. M. PAISLEY \\ AND A. M. SALEH \\ National Physical Laboratory, Teddington, Middlesex
}

(Received 25 November 1965)

\begin{abstract}
SUMMARY
The infrared absorption spectra of forty strains of sulphate-reducing bacteria have been recorded over the range $1800-800 \mathrm{~cm}^{-1}$. It was possible to identify positively Desulfovibrio gigas and the thermophilic Desulfotomaculum nigrificans. A broad differentiation was possible between salt-water and fresh-water forms of Desulfovibrio desulfuricans. Desulfotomaculum orientis and D. ruminis showed few characteristic differences from the fresh-water strains of $D$. desulfuricans but there was an indication that, with a more refined technique, at least one of the features otherwise characteristic of the other (thermophilic) desulfotomaculum species might be discerned. The results support to a considerable extent current views on the classification of the sulphate-reducers.
\end{abstract}

\section{INTRODUCTION}

A number of workers (e.g. Thomas \& Greenstreet, 1954; Riddle et al. 1956; Rideal \& Adams, 1957; Goulden \& Sharpe, 1958; Scopes, 1962) have considered the use of infrared (i.r.) spectroscopy as an aid to the identification of bacterial species or strains. While i.r. spectra of bacteria are very similar from organism to organism, small differences are detectable both in intensities and in the presence or absence of weak absorption bands. The present work was designed to investigate the i.r. spectra of a range of sulphate-reducing bacteria and to determine whether the organisms could be grouped in a manner consistent with their i.r. spectra, regardless of their current taxonomic classification.

\section{METHODS}

Choice and preparation of bacteria. Forty strains of sulphate-reducing bacteria were examined, the choice being determined by availability. These are listed below with the NCIB number in brackets.

\section{Desulfovibrio desulfuricans}

Group 1. Fresh-water strains: (Saunders, Campbell \& Postgate, 1964 and Dr L. L. Campbell, personal communication). Teddington M (8302), Hildenborough (8303), Wandle (8305), Holland D6 (8311), Beckton (8319), Marseilles (8386), Llanelly (8446), Monticello 2 (9442). Salt-water strain: Walvis Bay (8397). 
Group 2. Fresh-water strains : Essex 6 (8307), Teddington R (8312), Holland C6 (8372), Berre Eau (8387), Berre Sol (8388), 'Vibrio cholinicus' (9467). Salt-water strains: Norway 4 (8310), Venice 1 (8322), Canet 40 (8363), El Agheila Z (8380), Canet 20 (8391), Canet 32 (8392), Canet 41 (8393), Sylt 3 (9335), Aberdovey (9492).

Group 3. (Salt-requiring) El Agheila C (8308), California 43:63 (8364), Louisiana 43:11 (8365), Avonmouth (8398), British Guiana (8403).

\section{Desulfovibrio gigas}

Unnamed strain (9332).

Desulfotomaculum orientis (formerly Desulfovibrio orientis) (Campbell \& Postgate, 1965)

Singapore I (8382), Singapore II (8445).

Desulfotomaculum nigrificans (formerly Clostridium nigrificans thermophilic)

Teddington garden (8351), Staines G (8353), Holland CT (8356), Delft 3T (8359), Delft $15 \mathrm{~T}$ (8361), Delft 74T (8395), unnamed strain (8788).

\section{Desulfotomaculum ruminis}

Coleman 42 (8452).

The cultures were grown from the freeze-dried preparations at $30^{\circ}$ or $55^{\circ}$ as appropriate in Professor J. R. Postgate's modification of the medium C of Butlin, Adams \& Thomas (1949; see Baker, Papiska \& Campbell, 1962). NaCl 25 g./l. was added for salt-water forms. In each case, $1 \mathrm{ml}$. of stock culture (3-5 days old) was used as inoculum for $100 \mathrm{ml}$. of the above medium which was then incubated at the appropriate temperature under an atmosphere of nitrogen. The organisms were harvested by centrifugation for $7 \mathrm{~min}$. at $16,000 \mathrm{~g}$, resuspended in $0 \cdot 85 \% \mathrm{NaCl}(\mathrm{w} / \mathrm{v})$ and recentrifuged. The washing procedure was repeated 3 times and the final washed organisms suspended in $\mathbf{0 . 8 5} \%(\mathrm{w} / \mathrm{v}) \mathrm{NaCl}$ sufficient to ensure a concentration of $10 \mathrm{mg}$. dry wt. organisms $/ \mathrm{ml}$. The spectrum was then determined immediately. Experience showed that no substantial differences were observed in the spectra obtained from 1-, 3- or 6-day cultures; 3 days was therefore taken as a standard incubation time.

Measurement of infrared spectra. The spectra were recorded on a Grubb-Parsons GS 3 spectrometer. Programmed slits were used and loop gain and scanning speed were kept constant to minimize differences in response. The films were prepared on plates of the Kodak infrared optical material Irtran 2. This has advantages over the silver chloride plates used by earlier workers: a low background adsorption is obtainable and the use of a compensating plate in the reference beam is consequently unnecessary; in addition the material is quite stable and insensitive to light.

The suspensions of bacteria in $0.85 \%(w / v)$ aqueous saline were evaporated on the Irtran plates under infrared lamps. The plates were tilted slightly to form a concentration gradient of organisms across the plates. The plate carrying the dried film was mounted in the spectrometer and rotated until the absorption was $90 \pm 2 \%$ at $1650 \mathrm{~cm} .^{-1}$ and $5 \%$ at $1800 \mathrm{~cm} .^{-1}$. 


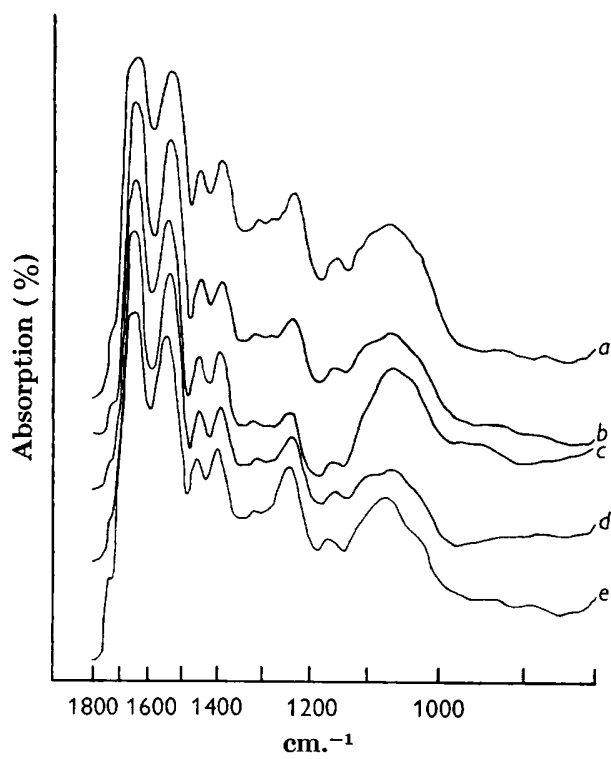

Fig. 1

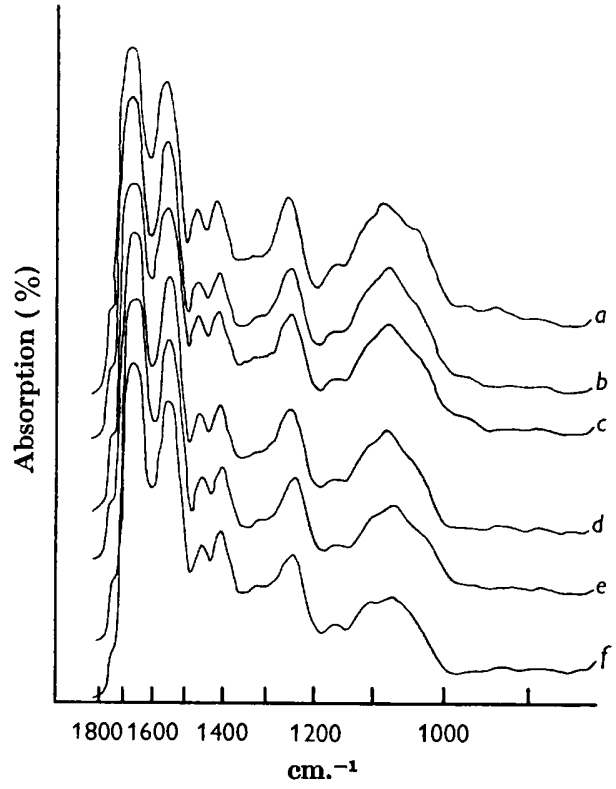

Fig. 3

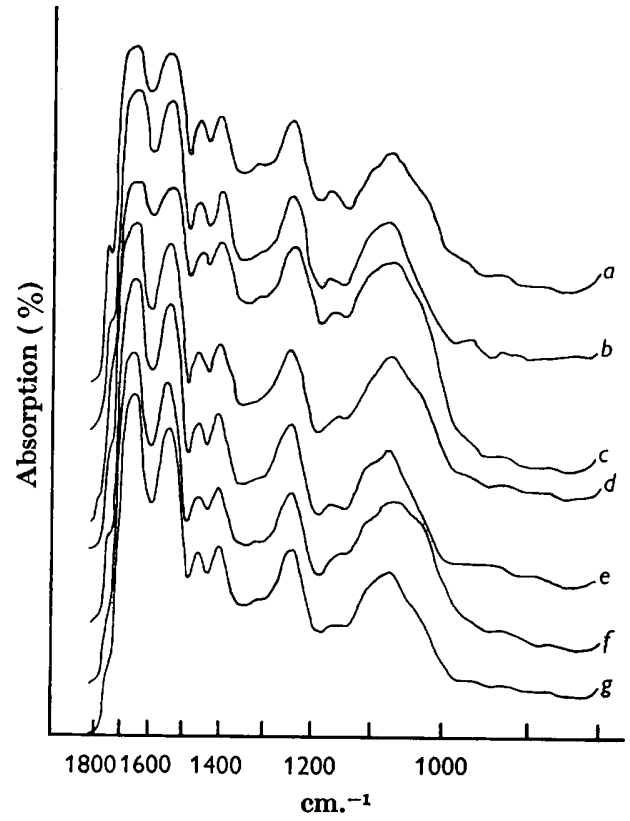

Fig. 2

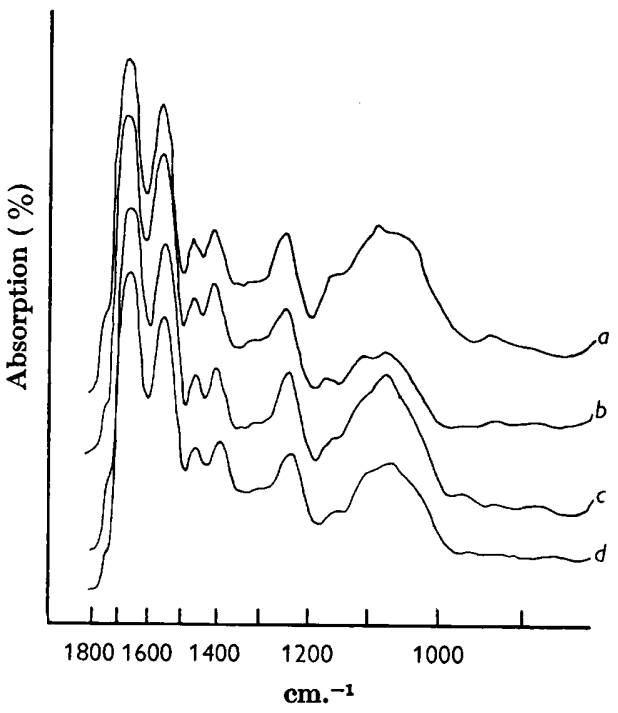

Fig. 4

Fig. 1. Typical infrared absorption spectra for thermophilic sulphate reducers, Desulfotomaculum nigrificans. $a$, Delft $15 \mathrm{~T}$; $b$, Staines G; $c$, Teddington garden; $d$, unnamed; $e$, Aberdovey (mesophilic).

Fig. 2. Typical i.r. absorption spectra for mesophilic salt-water sulphate reducers Desulfovibrio desulfuricans. $a$, British Guiana; b, El Agheila C; $c$, Louisiana 43:11; $d$, El Agheila $\mathrm{Z} ; e$, Sylt $3 ; f$, Canet 20 ; g, Norway 4 .

Fig. 3. Typical i.r. absorption spectra for mesophilic, fresh-water sulphate reducers Desulfovibrio desulfuricans. $a$, Hildenborough; b, 'Vibrio cholinicus'; $c$, Essex 6; $d$, Becton; $e$, Berre Eau; $f$, Singapore I.

Fig. 4. Infrared absorption spectra for some other sulphate reducers. $a$, Desulfovibrio gigas; $b$, Desulfotomaculum orientis Singapore I; $c, D$. orientis Singapore II; $d, D$. ruminis. 


\section{RESULTS}

Figures 1-4 show examples of the spectra obtained, grouped according to their points of similarity. The spectra have been spread along the ordinate axis to avoid superposition.

\section{Thermophilic organisms}

In the 1350-1200 cm..$^{-1}$ region, the spectra of nearly all of the sulphate-reducing bacteria examined had a weak band at $1312 \mathrm{~cm} .{ }^{-1}$, followed by a plateau leading into the band of relatively moderate intensity at $1240 \mathrm{~cm} .^{-1}$. A second, very weak, band was sometimes detectable at $1285 \mathrm{~cm}^{-1}$. In the present series this band appeared convincingly only in the thermophiles, with the single exception of strain Aberdovey. This organism is a mesophilic salt-water form and we were unable to obtain growth at $55^{\circ}$. Desulfotomaculum ruminis and the two examples of $D$. orientis showed a trace of the band at $1285 \mathrm{~cm} .^{-1}$.

\section{Mesophilic organisms}

Salt-water strains. In all the spectra examined, the intense band at $1650 \mathrm{~cm} .^{-1}$ had a higher frequency shoulder at about $1735 \mathrm{~cm}^{-1}$. This band varied slightly in frequency (it was at $1745 \mathrm{~cm} .^{-1}$ for strain British Guiana) but more importantly in intensity. In most of the spectra, it varied between 15 and $25 \%$ absorption. In a small number of cases, it was in the range $25-40 \%$ and in these cases the broad weak band at $940 \mathrm{~cm} .^{-1}$ also had a significantly higher intensity. The salt-water strains all had this characteristic with the exception of Norway 4. This strain is abnormal in other respects also (Miller \& Saleh, 1964), specifically in that it lacks the usual pigment desulfoviridin.

Between the bands at 1650 and $1355 \mathrm{~cm}^{-1}$, the absorption generally fell to between 60 and $65 \%$. However, in three cases, British Guiana, El Agheila C, and Louisiana $43: 11$ it fell to only $75-80 \%$. This particular subgroup of the salt-water strains also exhibits different behaviour to inhibitors (Saleh, 1964): all three strains are members of Group 3 of Saunders et al. (1964), and are obligate salt-water forms.

Fresh-water strains. The spectra of more than half of all the organisms examined did not show any of the above characteristics. These were all in the group of mesophilic, fresh-water strains and included the organism 'Vibrio cholinicus' (Hayward \& Stadtman, 1959) that was reassigned to the species Desulfovibrio desulfuricans by Baker et al. (1962).

The three organisms Desulfotomaculum orientis strain Singapore I and Singapore II and D. ruminis (8452) also fell into this group, except that they gave some slight indication of the very weak band at $1285 \mathrm{~cm}^{-1}$ which was otherwise a characteristic of the thermophilic group. This subgroup of organisms have other properties distinguishing them from the 'normal' mesophilic, fresh-water sulphatereducers, for example, they form spores (Adams \& Postgate, 1961). The close resemblance between the i.r. spectra of $D$. orientis and the D. ruminis is of particular interest, since, at their original classification, all three were assigned to the same species, Desulfovibrio orientis.

The most exceptional sulphate-reducing bacterium is Desulfovibrio gigas. In the spectrum of this organism, a quite sharp band appears at $1080 \mathrm{~cm} .^{-1}$ above the contour of the broad band extending from 1140 to $1000 \mathrm{~cm} .^{-1}$. In no other spectrum was this band observed. 


\section{CONCLUSIONS}

The sulphate-reducing bacteria can be divided into several reasonably well defined groups on the basis of their infrared absorption spectra. The groups correspond broadly with the current taxonomic classification of the organisms except that the members of the species of Desulfovibrio desulfuricans fall into two groups according to their marine or fresh-water origin, but without distinguishing between the groups of Saunders et al. (1964). D. gigas and Desulfotomaculum nigrificans are clearly distinguishable from other species. The other desulfotomaculum species are difficult to distinguish from the fresh-water desulfovibrio strains but there is some evidence that this might be possible with refined techniques. 'Cleaner' preparations, i.e. less contaminated with ferrous sulphide, and higher resolution spectroscopy are suggestions for refinement.

The work described above was done as part of the General Research Programme of the National Physical Laboratory and this paper is published by permission of the Director of the Laboratory.

\section{REFERENCES}

Adams, M. E. \& Postgate, J. R. (1961). On sporulation in sulphate-reducing bacteria. J. gen. Microbiol. 24, 291.

Baker, F. D., Papiska, H. R. \& Campbell, L. L. (1962). Choline fermentation by Desulfovibrio desulfuricans. J. Bact. 84, 973.

Butlin, K. R., Adams, M. E. \& Thomas, M. (1949). The isolation and cultivation of sulphate-reducing bacteria. J. gen. Microbiol. 3, 46 .

Campbell, L. L. \& Postgate, J. R. (1965). Classification of the spore-forming sulfatereducing bacteria. Bact. Rev. 29, 359.

Coleman, G. S. (1961). A sulphate-reducing bacterium from the sheep rumen. J. gen. Microbiol. 22, 423.

Goulden, J. D. S. \& Sharpe, M. E. (1958). The infrared absorption of Lactobacilli. J. gen. Microbiol. 19, 76.

Hayward, J. D. S. \& Stadtman, T. C. (1959). Anaerobic degradation of choline. J. Bact. 78, 557.

Mrller, J. D. A. \& SAleh, A. M. (1964). A sulphate-reducing bacterium containing cytochrome $c_{3}$ but lacking desulfoviridin. J. gen. Microbiol. 37, 419 .

Riddle, J. W., Kabler, P. W., Kenner, B. A., Bordner, R. H., Rockwood, S. A. Stevenson, H. J. R. (1956). Bacterial identification by infrared spectrophotometry. J. Bact. 72, 593.

Rideal, E. K. \& Adams, D. M. (1957). The interpretation and use of bacterial infrared spectra. Chemy. Ind. 762.

SALEH, A. M. (1964). Differences in the resistance of sulphate-reducing bacteria to inhibitors. J. gen. Microbiol. 37, 113.

Saunders, G. F., Campeeli, L. L. \& Postgate, J. R. (1964). Base composition of deoxyribonucleic acid of sulphate-reducing bacteria deduced from buoyant density measurement in cesium chloride. $J$. Bact. 87, 1093.

Scopes, A. W. (1962). The infrared spectra of some acetic acid bacteria. J. gen. Microbiol. $28,69$.

Thomas, L. C. \& Greenstreet, J. E. S. (1954). The identification of organisms by infrared spectrophotometry. Spectrochim. Acta, 6, 302. 